\title{
PENGARUH KEPEMIMPINAN KEPALA SEKOLAH, MOTIVASI KERJA DAN KEPUASAN KERJA TERHADAP KINERJA GURU PADA SMA NEGERI KECAMATAN KOTA JUANG KABUPATEN BIREUEN
}

\author{
Zubir $^{1)}$ dan Azhari ${ }^{* *}$ \\ ${ }^{1}$ Pegawai Dinas Pendidikan dan Kebudayaan Kabupaten Bireuen \\ 2 Dosen FE Universitas Almuslim Peusangan Bireuen \\ *) email: psmm.uniki@gmail.com
}

DOI:

https://doi.org/10.55178/idm.v2i3.214

ABSTRAK

Article history

Received:

March 12, 2021

Revised:

March 15, 2021

Accepted:

March 19, 2021

Page:

$52-62$

Kata kunci:

Principal Leadership,

Work Motivation,

Job Satisfaction,

Teacher Performance
The study was conducted on 116 state high school teachers in Juang City District, Bireuen Regency, with the aim of knowing the effect; 1). The leadership of the principal on the performance of the teachers of the State Senior High School of Juang City, Bireuen District. 2). Work motivation on the performance of teachers in SMA Negeri Juang City District, Bireuen Regency. 3). Job satisfaction with the performance of teachers of SMA Negeri, Kota Juang District, Bireuen Regency, as well as 4). The influence of principal leadership, work motivation and job satisfaction on the performance of teachers in SMA Negeri, Kota Juang District, Bireuen Regency. This type of research is quantitative with descriptive analysis methods and path analysis. The results of the research show, in a descriptive analysis that; a) Principal Leadership Factors including good in supporting teacher performance. The teacher assessment score on the Principal's Leadership reaches $82.59 \%$, b) The level of teacher work motivation, is already good, reaching $82.27 \%$ of the ideal conditions in achieving teacher performance, and c) Teacher job satisfaction has shown good things, reaching $82,88 \%$ of which is expected to improve teacher performance. While the results of the path analysis showed the influence of the principal's leadership on teacher performance was $7.97 \%$. There is an influence of the teacher work motivation factor on the performance of SMAN teachers in Juang City, Bireuen Regency, which is 9.44 percent. The job satisfaction factor is also a factor that has a very high effect on teacher performance, namely $15.11 \%$. The results of the analysis of the coefficient of determination explain that the contribution of the principal's leadership, work motivation and teacher job satisfaction to the performance of high school teachers in Juang City, Bireuen Regency, is $26.2 \%$.

\section{Pendahuluan (Introduction)}

Salah satu bentuk aktualisasi tugas guru sebagai tenaga profesional adalah diterbitkannya Undang-undang Nomor 20 Tahun 2003 tentang Sistem Pendidikan Nasional, Undang Undang Nomor 14 tahun 2005 tentang Guru dan Dosen dan Peraturan Pemerintah Nomor 19 tahun 2005 tentang Standar Nasional Pendidikan. Undang-undang dan peraturan pemerintah ini diharapkan dapat memfasilitasi guru untuk selalu mengembangkan keprofesiannya secara berkelanjutan. Pelaksanaan program pengembangan keprofesian berkelanjutan ini diharapkan dapat meningkatkan kompetensi pedagogik, profesional, sosial dan kepribadian untuk memenuhi kebutuhan dan tuntutan masa depan yang berkaitan dengan profesinya sebagai guru.

Masalah kepemimpinan selalu memberikan kesan yang menarik, sebab suatu organisasi akan berhasil atau gagal sebagian ditentukan oleh kualitas kepemimpinan. Kepemimpinan merupakan kemampuan untuk mempengaruhi, menggerakkan dan mengarahkan tindakan pada seseorang atau kelompok orang untuk mencapai tujuan tertentu pada situasi tertentu. Kepemimpinan merupakan salah satu aspek manajerial dalam kehidupan berorganisasi yang merupakan posisi kunci. Karena kepemimpinan seorang pemimpin berperan sebagai penyelaras dalam proses kerjasama antar manusia dalam organisasinya. 
Seorang pemimpin lembaga pendidikan/sekolah adalah kepala sekolah. Kepala sekolah merupakan pemimpin dalam suatu organisasi atau lembaga formal yaitu sekolah yang memiliki peranan penting untuk menentukan keberhasilan sekolah. Kepala sekolah yang berhasil adalah mereka yang memahami keberadaan sekolah sebagai organisasi yang bersifat kompleks dan unik, serta mampu melaksanakan tugas kepala sekolah, serta mampu bertanggung jawab untuk memimpin sekolah. Setiap kepala sekolah memiliki kemampuan untuk memimpin bawahannya dengan cara yang berbeda-beda. Di sisi lain, setiap guru memiliki persepsi yang berbeda satu sama lainnya mengenai kepemimpinan kepala sekolah. Apapun kepemimpinan kepala sekolah, yang penting kepemimpinan kepala sekolah itu mampu mendukung kinerja guru di sekolah.

Di samping itu untuk mewujudkan pengelolaan sekolah yang baik, perlu adanya kepala sekolah yang memiliki kemampuan sesuai tuntutan tugasnya. Untuk menjalankan tugas manajerial dan juga merespon tuntutan yang terus berubah saat ini, kepala sekolah harus memiliki kepemimpinan yang kuat agar mampu melaksanakan program-program sekolah yang mereka bina secara efektif. Setiap kepala sekolah dasar sebagai pemimpin organisasi perlu menguasai dan mempunyai kemampuan untuk memotivasi bawahannya, agar kepala sekolah dasar dapat mempengaruhi bawahannya harus memahami apa yang menjadi kebutuhan bawahannya. Keberhasilan pengelolaan sekolah sangat ditentukan oleh kegiatan pendayagunaan sumber daya manusia. Oleh karena itu kepala sekolah sebagai pemimpin dalam suatu organisasi hendaknya menyadari dan tanggap teknik-teknik untuk dapat memelihara prestasi dan kepuasan kerja guru antara lain dengan memberikan dorongan kepada guru agar dapat melaksanakan tugas mereka sesuai dengan aturan dan pengarahan. Yang pada gilirannya akan tercipta kepuasan dan kinerja yang tinggi.

Pengamatan awal peneliti pada SMA Negeri Kota Juang Kabupaten Bireuen, di dapatkan bahwa tingkat kinerja guru masih rendah. Ini berdasarkan hasil supervisi dan pemantauan pengawas tahun 2017 dan 2018 menunjukan bahwa kinerja guru SMA Negeri Kecamatan Kota Juang masih di bawah standar nasional. Sementara rapor mutu guru dai LPMP Aceh dalam uji kompetensi guru (UKG) SMA Negeri Kecamatan Kota Juang sejak 2015 hingga 2017 rata-rata masih di bawah 70 dari nilai maksimal 100. Dari rata-rata nasional Aceh masih 10 besar rangking di bawah. Fenomena rendahnya kinerja guru tersebut tentu akan berdampak terhadap sikap dan perilaku guru dalam melaksanakan tugas pokoknya sebagai tenaga pendidk , sehingga tujuan pendidikan tidak dapat tercapai dengan optimal. Hal ini tidak terjadi sendirinya tanpa dipengaruhi oleh berbagai faktor, baik dari dalam maupun dari luar diri guru itu sendiri.

Hal lain dalam terkait dengan kinerja guru adanya motivasi yang tinggi untuk berprestasi. Motivasi kerja sangat penting bagi seorang guru, mengingat motivasi merupakan energi yang menggerakkan guru untuk bekerja. Tanpa adanya motivasi kerja dari guru, mereka akan bekerja apa adanya dan terkesan asal bekerja. Berdasarkan, hasil observasi menunjukkan motivasi kerja guru terkesan masih belum optimal dapat dilihat dari pengaruh kepala sekolah dalam memberikan motivasi kerja kepada guru masih kurang maksimal seperti kurangnya motivasi dan pembinaan yang diberikan oleh kepala sekolah kepada guru dalam melaksanakan tugas dan tanggung jawab sebagai guru, rasa tanggung jawab yang masih kurang dalam melaksanakan tugas sebagai guru, kurangnya penghargaan yang diberikan terhadap guru yang berprestasi

Juga pimpinan harus mengevaluasi kepuasan kerja. Kepuasan kerja guru pada SMA Negeri Kota Juang Kabupaten Bireuen yang dipengaruhi oleh rendahnya kompensasi yang diberikan kepada guru, hubungan dengan rekan sekerja yang kurang harmonis, dan kurangnya promosi jabatan. Kepuasan kerja dapat dirasakan mulai dari pemberian motivasi, budaya organisasi yang ada dalam organisasi dan termasuk lingkungan kerja yang sehat. Faktor itu perlu diperhatikan oleh pimpinan sekolah yaitu Kepala Sekolah yang menyelenggarakan dan melaksanakan tugas pendidikan nasional yang ada di negara kita dan ini masih terjadi di SMA Negeri Kecamatan Kota Juang. Peran Kepala sekolah sangat mempengaruhi para pegawai dan bawahannya. Mereka bekerja penuh antusias dan keinginan yang tinggi, diharapkan bagi mereka bisa mendapatkan penghormatan dan kesejahteraan didalam bekerja. Hal ini masih perlu diperhatikan lebih jauh agar kinerja para guru pada SMAN Kecamatan Kota Juang dapat merasakan kepuasan

Kinerja guru dipengaruhi oleh tingkat kepuasan guru yang dirasakannya selama dalam pelaksanaan pendidikan. Sekolah merupakan wadah tempat belajar dan pembelajaran pendidikan nasional. Kualitas kinerja guru sangat dituntut untuk dapat memberikan pelayanan pendidikan sesuai dengan standar, pencapaian tujuan tersebut mestinya diperlukan kualitas kinerja yang diiringi dengan rasa kepuasan bagi petugas pelaksana tersebut. Kinerja guru merupakan hal pokok yang menentukan baik buruknya pendidikan di sekolah. Sehingga penulis menyimpulkan bahwa masalah-masalah yang mengenai kinerja guru, dan dari hasil observasi masalah pokok yang memengaruhi kinerja guru adalah kepemimpinan, motivasi kerja dan kepuasan kerja. Berdasarkan latar belakang tersebut, sehingga penulis perlu mengangkat penelitian yang 
berjudul "Pengaruh Kepemimpinan Kepala Sekolah, Motivasi Kerja dan Kepuasan Kerja Terhadap Kinerja Guru SMA Negeri Kecamatan Kota Juang Kabupaten Bireuen".

\section{Tinjauan Literatur (Literature Review)}

\section{a. Pengaruh Kepemimpinan Kepala Sekolah terhadap Kinerja Guru}

Kepala sekolah adalah seorang tenaga fungsional guru yang diberi tugas tambahan untuk memimpin suatu sekolah di mana diselenggarakan proses belajar mengajar. Dalam menjalankan tugas dan fungsi kepemimpinan kepala sekolah harus mempunyai kemampuan untuk menggerakkan, mengerahkan, membimbing, melindungi, membina, memberi teladan, memberi dorongan, dan memberi bantuan terhadap semua sumber daya manusia yang ada di suatu sekolah sehingga dapat didayagunakan secara maksimal untuk mencapai tujuan yang telah ditetapkan (Wahjosumidjo, 2005: 83). Dalam penelitian ini akan dikaji kepemimpinan kepala sekolah dalam melaksanakan tugas pokok dan fungsinya sebagai kepala sekolah dan bukan mengkaji tentang gayanya, melainkan performance dan pola perilakunya dalam pelaksanaan tugas tersebut.

Kepemimpinan adalah norma perilaku yang digunakan oleh seseorang pemimpin pada saat dia mencoba mempengaruhi perilaku orang lain seperti yang ia lihat. Norma perilaku tersebut diaplikasikan dalam bentuk tindakan-tindakan dalam aktifitas kepemimpinannya untuk mencapai tujuan suatu organisasi melalui orang lain. Kepemimpinan Kepala Sekolah sangat mewarnai kondisi kerja. Kebijakan, pengaruh sosial dengan para guru serta para murid dan juga tindakannya dalam membuat berbagai kebijakan, kondisi tersebut memberikan dampak pula terhadap kinerja para guru. Kinerja merupakan perasaan dorongan yang diinginkan oleh guru dalam berkerja. Dengan demikian diduga terdapat hubungan positif kepemimpinan kepala sekolah dengan kinerja guru sekolah dasar. Hal ini dapat dikatakan pula semakin baik kepemimpinan kepala sekolah semakin meningkat pula kinerja guru.

\section{b. Pengaruh Motivasi terhadap Kinerja Guru}

Motivasi merupakan sesuatu yang timbul dari hati nurani sesorang, baik motivasi yang berasal dari dalam diri maupun luar. Dengan timbulnya suatu motivasi yang ada pada seorang guru, diharapkan kinerja guru dapatditingkatkan supaya pendidikan yang ada dapat berkembang sesuai yang diharapkan oleh negara. Motivasi kerja guru merupakan daya dorong atau daya gerak yang dapat membangkitkan dan mengarahkan perilaku guru pada suatu perbuatan atau pekerjaan.Guru yang memiliki motivasi tinggi akan berusaha untuk memberikan yang terbaik yang dapat dilakukannya, karenadia mempunyai komitmen yang tinggi terhadap panggilan profesinya. Motivasi kerja guru sangat berhubungan terhadap peningkatan kualitas kinerja guru. Apabila seorang guru memiliki motivasi yang tinggi, maka kinerja guru tersebut meningkat. Akan tetapi, apabila seorang guru memiliki motivasi yang rendah,maka kinerja guru tersebut mengalami penurunan.Guru bekerja tidak hanyakarena ingin dipuji atau untuk mendapatkan imbalan, tetapi lebih dari itu karena tuntutan profesinya.

Eri Agustin (2015), dalam penelitiannya tentang Pengaruh Motivasi Kerja Terhadap Kinerja Guru Sekolah Dasar Dabin IV Kecamatan Kajen Kabupaten Pekalongan. Skripsi, Jurusan Pendidikan Guru Sekolah Dasar. Menyatakan Motivasi intrinsik dan ekstrinsik merupakan faktor yang dapat mempengaruhi kinerja guru sekolah dasar. Motivasi kerja memberikan dorongan terhadap para guru agar kinerja guru yang dihasilkan dapat lebih maksimal. Namun yang dijumpai di Dabin IV Kecamatan Kajen Kabupaten Pekalongan kinerja guru yang dihasilkan belum maksimal. Hal ini diduga karena karena motivasi yang dimiliki tiap individu guru berbeda dan dapat berubah-ubah. Hasil yang diperoleh menunjukkan bahwa 44,1\% kinerja guru Sekolah Dasar dipengaruhi oleh Motivasi kerja.

Penelitian Cici Asterya Dewi (2012) tentang Pengaruh Motivasi Kerja Terhadap Kinerja Guru Honorer (Studi Kasus Guru Honorer Sman Rumpun IPSSe-Kecamatan Temanggung), menunjukkan bahwa motivasi kerja berpengaruh positif dan signifikan terhadap kinerja guru honorer. Berdasarkan hasil penelitian diketahui motivasi kerja menghasilkan koefisien regresi 0,381 . Sebesar $14,6 \%$ motivasi kerja dapat mempengaruhi kinerja guru honorer. Senada dengan itu penelitian lain Titin Eka Ardiana tentang Pengaruh Motivasi Kerja Guru Terhadap Kinerja Guru Akuntansi SMK di Kota Madiun. Menyatakan motivasi kerja mempunyai pengaruh yang signifikan terhadap kinerja guru akuntansi. Hasil statistik mengukur bahwa motivasi kerja berpengaruh secara positif terhadap kinerja guru akuntansi dengan kontribusi sebesar $80,6 \%$,

\section{c. Pengaruh Kepuasan Kerja terhadap Kinerja Guru}

Kepuasan kerja sangat penting untuk mengaktualisasikan diri. Pegawai yang tidak memperoleh kepuasan kerja mereka tidak akan pernah mencapai kematangan psikologis dan pada gilirannya akan menjadi frustasi 
dalam bekerja kemudian akan berpengaruh terhadap kinerjanya. Pegawai seperti ini akan sering melamun, semangat kerja rendah, cepat lelah dan bosan, emosionalnya tidak stabil, sering tidak hadir dan melakukan kesibukan yang tidak stabil, sering tidak hadir dan melakukan kesibukan yang tidak ada hubungannya dengan pekerjaan yang harus dilakukan.

Penelitian lain membuktikan bahwa adanya pengaruh kepuasan kerja terhadap kinerja guru seperti yang telah dilakukan oleh Anis Yasinta dalam skripsinya mengatakan, Kepuasan kerja adalah sikap yang dikembangkan para karyawan sepanjang waktu mengenai berbagai segi pekerjaannya, seperti upah, gaya penyeliaan, dan rekan sekerja. Saat orang-orang berbicara mengenai sikap pekerja, mereka biasanya merujuk pada kepuasan kerja, yang menjelaskan suatu perasaan psitif tentang pekerjaan, yang dihasilkan dari suatu evaluasi pada karakteristik-karakteristiknya. Seseorang dengan tingkat kepuasan tinggi memiliki perasaan yang positi mengenai pekerjaannya, sedangkan seseorang dengan level yang rendah memiliki perasaan yang negatif.

Hasil penelitian Pujiyanti dan SB. Handayani (2012), berjudul "Pengaruh Kepuasan Kerja Terhadap Kinerja Guru Dengan Kepemimpinan Kepala Sekolah dan Pemberdayaan Guru Sebagai Variabel Moderasi Pada SD Negeri UPTD DIKPORA Kecamatan Sayung Demak". Hasil pengujian statistic membuktikan hipotesi ini. Hal ini dapat diinterpretasikan bahwa adanya kepemimpinan kepala sekolah yang baik dan pemberdayaan guru yang optimal akan memperkuat pengaruh kepuasan kerja terhadap kinerja guru.

Senada dengan hal ini, Febry Zakharia (2014), dengan penelitian "Pengaruh Budaya Organisasi dan Kepuasan Kerja Terhadap Kinerja Guru SMP Yadika 3 Tangerang, menyatakan bahwa kepuasan kerja berpengaruh signifikan terhadap kinerja guru di SMP YADIKA 3 Tangerang, Menurut penelitian Mulyanto (2012), kepuasan kerja juga mempunyai pengaruh yang signifikan terhadap kinerja guru.

Berdasarkan uraian di atas penulis dapat menggambarkan kerangka pemikiran sebagai berikut :

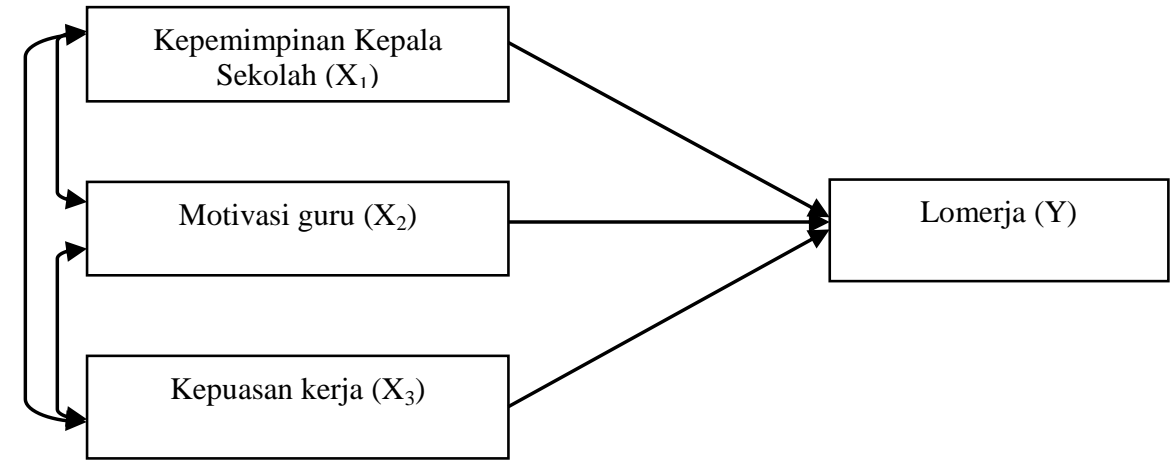

Gambar 1. Kerangka Pemikiran

\section{Metode Penelitian (Methodology)}

\section{a. Metode dan Variabel Penelitian}

Penelitian ini menggunakan riset deskriptif dan kausal komparatif (causal comparative research). Riset deskriptif yaitu penelitian yang menjelaskan atau memberi paparan pada variabel yang diteliti dan ketergantungan variabel pada sub variabelnya. Riset deskriptif merupakan penelitian terhadap masalahmasalah berupa fakta-fakta saat ini dari suatu populasi.

Kausal komparatif (causal comparative research) yang dimaksudkan guna menunjukkan arah pengaruh antara variabel bebas dengan variabel terikat sehingga tujuan dari penelitian ini yaitu untuk melihat bagaimana pengaruh suatu variabel terhadap variabel lainnya. Unit analisis dalam penelitian ini adalah guru pada SMAN di Kota Juang Kabupaten Bireuen.

Adapun variabel, dimensi dan indikator pengukurnya di definisikan berikut ini.

Tabel 1. Operasional Variabel Penelitian

\begin{tabular}{|l|l|l|}
\hline \multicolumn{1}{|c|}{ Variabel } & \multicolumn{1}{|c|}{ Defenisi Konsep } & \multicolumn{1}{c|}{ Dimensi } \\
\hline Kepemimpinan & Kepemimpinan adalah sifat, karakter, atau cara & a. Inovator \\
Kepala Sekolah & seseorang dalam upaya membina dan menggerakkan & b. Komunikator \\
$\left(\mathrm{X}_{1}\right)$ & seseorang atau sekelompok orang agar mereka & c. Motivator \\
& bersedia, komitmen dan setia untuk melaksanakan & d. Kontroler \\
\hline
\end{tabular}




\begin{tabular}{|c|c|c|}
\hline & $\begin{array}{l}\text { kegiatan sesuai dengan tugas dan tanggung jawab } \\
\text { untuk mewujudkan tujuan organisasi yang telah } \\
\text { ditetapkan sebelumnya. Thoha }(2010: 15)\end{array}$ & \\
\hline $\begin{array}{l}\text { Motivasi Kerja } \\
\left(\mathrm{X}_{2}\right)\end{array}$ & $\begin{array}{l}\text { Motivasi adalah pemberian daya penggerak yang } \\
\text { menciptakan kegairahan kerja seseorang, agar mereka } \\
\text { mau bekerja sama, bekerja efektif dan terintegrasi } \\
\text { dalam segala daya upayanya untuk mencapai } \\
\text { kepuasan. Hasibuan (2014:95) }\end{array}$ & $\begin{array}{l}\text { a. Kebutuhan untuk berprestasi } \\
\text { b. Kebutuhan memperluas } \\
\text { pergaulan } \\
\text { c. Kebutuhan untuk menguasai } \\
\text { sesuatu pekerjaan }\end{array}$ \\
\hline $\begin{array}{l}\text { Kepuasan } \\
\text { Kerja } \\
\left(\mathrm{X}_{3}\right)\end{array}$ & $\begin{array}{l}\text { Kepuasan kerja adalah sikap emosional yang } \\
\text { menyenangkan dan mencintai pekerjaannya. Sikap ini } \\
\text { dicerminkan oleh moral kerja. Hasibuan (2010:117) }\end{array}$ & $\begin{array}{l}\text { a. Kepuasan terhadap Pekerjaan } \\
\text { b. Kepuasan terhadap Imbalan } \\
\text { c. Kepuasan terhadap Supervisi } \\
\text { Atasan } \\
\text { d. Kepuasan terhadap Rekan Kerja } \\
\text { e. Kesempatan Promosi } \\
\end{array}$ \\
\hline $\begin{array}{l}\text { Kinerja Guru } \\
(\mathrm{Y})\end{array}$ & $\begin{array}{l}\text { Kinerja (prestasi kerja) adalah hasil kerja secara } \\
\text { kualitas dan kuantitas yang dicapai seorang karyawan } \\
\text { dalam melaksanakan tugasnya sesuai dengan tanggung } \\
\text { jawab yang diberikan kepadanya. Mangkunegara } \\
(2011: 67)\end{array}$ & $\begin{array}{l}\text { a. Kuantitas } \\
\text { b. Kualitas } \\
\text { c. Waktu } \\
\text { d. Biaya }\end{array}$ \\
\hline
\end{tabular}

\section{b. Populasi dan Sampel Penelitian}

Jumlah semua guru yang merupakan Aparatur Sipil Negara (ASN) dari 3 (tiga) SMA Negeri di Kota Juang yang selanjutnya menjadi populasi dari penelitian ini sebanyak 164 orang, terdiri dari 61 orang guru $(37,20 \%)$ berasal dari SMA Negeri 1 Bireuen, 55 orang guru $(33,54 \%)$ berasal dari SMA Negeri 2 Bireuen, dan 48 orang guru $(29,26 \%)$ berasal dari SMA Negeri 3 Bireuen.

Sampel penelitian ini adalah sebagian dari Guru sengan rumusan yang digunakan dalam penetapan jumlah sampel berdasarkan rumus Slovin dengan taraf signifikan $\alpha=0,05$, yakni 116 guru.

\section{c. Metode Analisis}

Metode analisis data menggunakan pendekatan Analisis Jalur (Path Analysis). Sebelum dilakukan analisis data atau perhitungan statistic terlebih dahulu dilakukan uji asumsi normalitas, uji linearitas, uji autokorelasi dan uji multikolonieritas. Keempat uji tersebut meupakan persyaratan sebelum melakukan embuktian terhadap hipotesis penelitian.Hal ini merupakan bagian dari statistic inferensial tipe parametris hanya dapat digunakan jika persyaratan analisis terpenuhi.

Alasan menggunakan analisis jalur karena metode ini dapat menganalisis pola hubungan kausal antara variabel dengan tujuan untuk mengertahui pengaruh langsung dan tidak langsung, secara serempak atau bersama-sama dan parsial atai mandiri, beberapa variabel penyebab terhadap sebuah variabel akaibat.

Analisis jalur meupakan bagian dari model regresi yang dapat digunakan untuk menganalisis hubungan sebab akbat antar saru variabel dengan variabel lainnya. Dalam analisis jalur pengaruh independen dan dependen dapat berupa pengaruh langsung dan pengaruh tdak langsung (direct indirect effect) atau dengan akta lain analysis jalur memperhitungkan adanya pengaruh langsung dan tidak langsung. Pengaruh tidak langsung suatu independent variabel terhadap dependent variabel adalah melalui yang lain disebut variabel antara atau mediasi (intervening variable). Untuk menggambarkan hubungan-hubungan kausal antar variabel yang akan diteliti pada penelitian ini digunakan diagram jalur (path diagram).

Model struktural secara umum dapat digambarkan dengan persamaan sebagai berikut : $\mathrm{Y}=f\left(\mathrm{X}_{1}, \mathrm{X}_{2}, \mathrm{X}_{3}\right)$. Diagram jalur dan persamaan struktural penelitian ini adalah seperti terlihat pada Gambar 1 berikut :
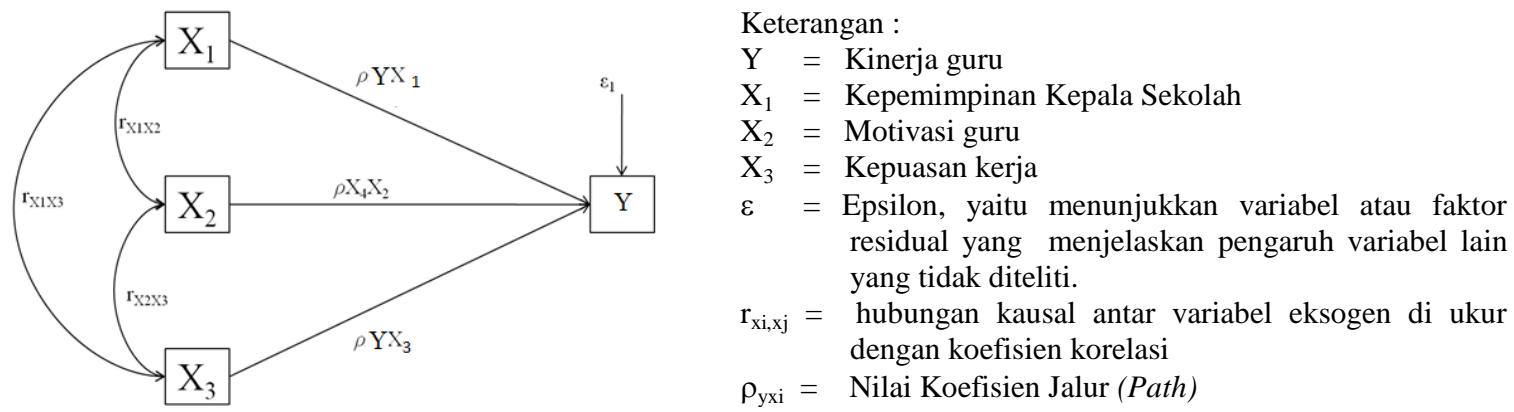
residual yang menjelaskan pengaruh variabel lain yang tidak diteliti.

$r_{x i, x j}=$ hubungan kausal antar variabel eksogen di ukur dengan koefisien korelasi

$\rho_{\mathrm{yxi}}=$ Nilai Koefisien Jalur (Path)

Gambar 1 Diagram Jalur Penelitian 


\section{Hasil dan Pembahasan (Results and Discussion)}

\section{a. Uji Coba Instrumen Penelitian}

Hasil uji coba instrument, diawali dengan menyebarkan angket terhadap 30 responden. Kemudian dilakukan tabulasi data kedalam tabel induk penelitian. Setelah itu dilakukan pengujian validitas dan reliabilitas terhadap kuesioner yang akan digunakan. Apabila instrument tersebut valid maka instrument tersebut dapat digunakan dalam penelitian dan bila tidak valid maka instrument tersebut, harus dilakukan perbaikan, atau dengan menghilangkan butir-butir pernyataan yang tidak valid, dan mengakibatkan tidak reliabel.

Data hasil angket yang diisi responden diberi skor degan skala likert yang dikategorikan memiliki skala data ordinal, yakni dengan jawaban pilihan pada angket atau kuesoner tertutup. Jawabannya adalah dari Sangat tidak setuju, sampai sangat setuju, sehingga bobot nilai yang diberikan antara 1 sampai 5 yang memiliki skala data ordinal. Oleh karenanya dalam menghitung korealsi setiap skor item dengan skor totalnya (dengan menganggap skor butir pertanyaan sebagai nilai $\mathrm{x}_{\mathrm{i}}$ dan skor total sebagai nilai $\mathrm{X}$ ), digunakan rumusan Koefisien korelasi Rank-Spearman. Hasilnya berikut ini:

Tabel 1. Uji Coba Validitas Instrumen untuk Kepemimpinan Kepala Sekolah $\left(\mathrm{X}_{1}\right)$

\begin{tabular}{|c|l|c|c|c|}
\hline Butir & \multicolumn{1}{|c|}{ Pernyataan } & r-hitung & r-tabel & Keputusan \\
\hline 1 & $\begin{array}{l}\text { Kepala Sekolah mempunyai tanggung jawab besar terhadap keberhasilan } \\
\text { sekolah }\end{array}$ & 0,589 & 0,361 & Valid \\
\hline 2 & Kepala Sekolah Melakukan monitoring dan evaluasi Proses Belajar Mengajar & 0,779 & 0,361 & Valid \\
\hline 3 & $\begin{array}{l}\text { Kepala Sekolah selalu menggunakan kesempatan untuk berkomunikasi dengan } \\
\text { guru }\end{array}$ & 0,694 & 0,361 & Valid \\
\hline 4 & $\begin{array}{l}\text { Kepala Sekolah bersedia menerima guru setiap saat, baik pada jam dinas mau } \\
\text { pun di luar jam dinas }\end{array}$ & 0,553 & 0,361 & Valid \\
\hline 5 & $\begin{array}{l}\text { Setiap masukan untuk pengembangan sekolah ditanggapi dengan positif oleh } \\
\text { Kepala Sekolah }\end{array}$ & 0,643 & 0,361 & Valid \\
\hline 6 & $\begin{array}{l}\text { Sebelum menyusun rencana kegiatan sekolah, Kepala Sekolah diskusikan } \\
\text { dengan para guru }\end{array}$ & 0,821 & 0,361 & Valid \\
\hline 7 & Setiap kegiatan direncanakan dengan baik oleh Kepala Sekolah & 0,586 & 0,361 & Valid \\
\hline 8 & Setiap tugas dikoordinir dengan baik oleh Kepala Sekolah & 0,726 & 0,361 & Valid \\
\hline 9 & Kepala Sekolah sudah menjadwalkan semua tugas guru & 0,520 & 0,361 & Valid \\
\hline 10 & Kepala Sekolah memberikan petunjuk pelaksanaan tugas dengan jelas & 0,440 & 0,361 & Valid \\
\hline
\end{tabular}

Sumber: Hasil olah data, 2020.

Dari hasil perhitungan validitas variabel diatas, tampak semua butir pernyataan dinyatakan valid, karena nilai $\mathrm{r}_{\text {-hitung }}$ semua diatas kriteria $\mathrm{r}$-tabel $=0,361$ pada taraf uji $\alpha=5 \%$. Sehingga semua butir pernyataan dalam angket yang mengukur variabel Kepemimpinan Kepala sekolah SMAN di Kecamatan Kota Juang Kabupaten Bireuen, dinyatakan valid.

Tabel 2. Uji Coba Validitas Instrumen untuk Variabel Motivasi Guru $\left(\mathrm{X}_{2}\right)$

\begin{tabular}{|c|c|c|c|c|}
\hline Butir & Pernyataan & r-hitung & r-tabel & Keputusan \\
\hline 1 & $\begin{array}{l}\text { Dalam bekerja saya berkeinginan memberikan segala upaya yang ada untuk } \\
\text { membantu sekolah ini menjadi sukses }\end{array}$ & 0,417 & 0,361 & Valid \\
\hline 2 & $\begin{array}{l}\text { Dalam menghadapi ujian, saya berupaya melakukan les tambahan kepada siswa di } \\
\text { luar jam sekolah }\end{array}$ & 0,544 & 0,361 & Valid \\
\hline 3 & $\begin{array}{l}\text { Dalam keadaan terpaksa seperti sakit, saya meminta ijin kepada kepala sekolah } \\
\text { untuk tidak mengajar namun tetap memberikan tugas untuk siswanya }\end{array}$ & 0,433 & 0,361 & Valid \\
\hline 4 & Sebagai guru, saya lebih mementingkan tugas pokok dari pada urusan pribadi & 0,445 & 0,361 & Valid \\
\hline 5 & $\begin{array}{l}\text { Saya tidak perlu mencurahkan segala kemampuan untuk mengerjakan tugas yang } \\
\text { diberikan oleh pimpinan }\end{array}$ & 0,341 & 0,361 & Tdk Valid \\
\hline 6 & Dalam melaksanakan tugas saya tidak berusaha untuk mengajar sebaik mungkin & 0,272 & 0,361 & Tdk Valid \\
\hline 7 & $\begin{array}{l}\text { Saya akan merasa senang apabila siswa kelak menjadi orang yang terhormat di } \\
\text { masyarakat }\end{array}$ & 0,624 & 0,361 & Valid \\
\hline 8 & $\begin{array}{l}\text { Saya mempunyai semangat kerja yang tinggi untuk tercapainya tujuan sekolah } \\
\text { yang telah di programkan }\end{array}$ & 0,527 & 0,361 & Valid \\
\hline 9 & $\begin{array}{l}\text { Saya bekerja disamping untuk beribadah, juga untuk memenuhi kebutuhan } \\
\text { keluarga }\end{array}$ & 0,473 & 0,361 & Valid \\
\hline 10 & $\begin{array}{l}\text { Saya berusaha bekerja secara mandiri dalam tugas saya, tanpa menggantungkan } \\
\text { diri pada orang lain }\end{array}$ & 0,543 & 0,361 & Valid \\
\hline
\end{tabular}

Sumber: Hasil Olah Data, 2020.

Dari hasil perhitungan validitas variabel Motivasi kerja guru diatas, tampak terdapat 8 butir pernyataan dinyatakan valid, karena nilai $\mathrm{r}_{- \text {hitung }}$ semua diatas kriteria $\mathrm{r}$ tabel $=0,361$. Sedangkan butir pernyataan nomor 5 dan 6 tidak valid, karena r-hitung < dari r-tabel pada taraf uji 5\%. Sehingga hanya 8 butir 
pernyataan yang valid dalam angket yang mengukur variabel Motivasi kerja guru SMAN di Kecamatan Kota Juang Kabupaten Bireuen.

Tabel 3. Uji Coba Validitas Instrumen untuk Variabel Kepuasan kerja guru $\left(\mathrm{X}_{3}\right)$

\begin{tabular}{|c|l|c|c|c|}
\hline Butir & \multicolumn{1}{|c|}{ Pernyataan } & r-hitung & r-tabel & Keputusan \\
\hline 1 & Gaji saya cukup, sesuai dengan tanggungjawab yang saya pikul & 0,490 & 0,361 & Valid \\
\hline 2 & Gaji saya sesuai dengan pekerjaan yang saya lakukan & 0,474 & 0,361 & Valid \\
\hline 3 & Tunjangan penting dalam menambah jumlah gaji & 0,830 & 0,361 & Valid \\
\hline 4 & Kepala sekolah memberikan dukungan kepada saya saat bekerja & 0,800 & 0,361 & Valid \\
\hline 5 & Kepala sekolah memberikan motivasi kerja yang tinggi kepada para guru & 0,734 & 0,361 & Valid \\
\hline 6 & Rekan kerja guru memiliki tanggungjawab dalam menyelesaikan pekerjaan & 0,480 & 0,361 & Valid \\
\hline 7 & Rekan kerja guru membantu saya dalam melakukan pekerjaan & 0,546 & 0,361 & Valid \\
\hline 8 & Saya bertanggungjawab dalam menyelesaikan pekerjaan & 0,800 & 0,361 & Valid \\
\hline 9 & $\begin{array}{l}\text { Saya banyak mendapatkan keberhasilan dalam melakukan pekerjaan sebagai } \\
\text { guru }\end{array}$ & 0,481 & 0,361 & Valid \\
\hline 10 & Saya menikmati pekerjaan sebagai guru & 0,494 & 0,361 & Valid \\
\hline
\end{tabular}

Sumber: Hasil olah data penelitian, 2020.

Dari hasil perhitungan validitas variabel kepuasan kerja guru ini, tampak semua butir pernyataan valid. Hal ini terjadi karena nilai $\mathrm{r}_{\text {-hitung }}$ diatas kriteria $\mathrm{r}$-tabel $=0,361$. Sehingga ke-10 butir pernyataan dalam angket yang mengukur variabel kepuasan kerja guru SMAN di Kecamatan Kota Juang Kabupaten Bireuen, dinyatakan valid.

Selanjutnya dilakukan uji reliabilitas interumen, bertujuan untuk menguji kehandalan atau kepercayaan pengungkapan data. Pengukuran yang memiliki reliabilitas tinggi adalah pengukuran yang mampu memberikan hasil yang dipercaya (reliable). Data yang valid diolah dengan teknik tertentu, dalam hal ini yang digunakan adalah teknik Alpha Cronbach. Suatu data dikatakan reliabel jika memberikan nilai Cronbach's Alpha > 0,60 (Ghozali, 2003). Hasil uji reliabilitas semua variabel ditunjukkan dalam tabel berikut:

Tabel 4. Hasil Uji Reliabilitas Instrumen Variabel

\begin{tabular}{|cl|c|c|c|}
\hline \multicolumn{1}{|c|}{ Variabel } & Cronbach's Alpha & N of Items & Keterangan \\
\hline- & Kepemimpinan Kepsek & 0,853 & 10 & Reliabiltas Tinggi \\
\hline- & Motivasi kerja guru & 0,752 & 8 & Reliabiltas Sedang \\
\hline- & Kepuasan kerja guru & 0,818 & 10 & Reliabiltas Tinggi \\
\hline
\end{tabular}

Sumber : Hasil Uji coba Peneltian, 2020

Menurut Sekaran (2006), bahwa reabilitas yang kurang dari 0,6 adalah kurang baik, sedangkan 0,7 dapat diterima dan reliabilitas dengan Cronbach's Alpha 0,8 atau di atasnya adalah lebih baik. Berdasarkan output yang diperoleh dari tabel di atas, diperoleh nilai koefisien reliabilitas pada semua variabel adalah realiable, dan hasilnya tinggi dan sedang.

\section{b. Hasil analisis Deskriptif}

Secara deskriptif akan diukur persepsi pegawai tentang varibel yang diteliti sehingga mendapatkan gambaran mengenai suatu data yang akan diteliti atau untuk menguraikan kecenderungan jawaban responden dari tiap-tiap variabel. Hasilnya, sebagai berikut.

Tabel 5. Deskripsi Pegawai tentang Variabel Penelitian

\begin{tabular}{|c|c|c|c|c|c|c|}
\hline \multirow{2}{*}{ Variabel } & \multicolumn{5}{|c|}{ Persentase Jawaban } & \multirow{2}{*}{$\begin{array}{c}\text { Skor } \\
\text { Pencapaian }\end{array}$} \\
\hline & SS & $\mathbf{S}$ & KS & TS & STS & \\
\hline 1. Kepemimpinan Kepala Sekolah & 0,00 & 2,84 & 9,91 & 58,71 & 28,53 & $82,59 \%$ \\
\hline 2. Motivasi guru & 0,00 & 1,40 & 14,90 & 54,64 & 29,05 & $82,27 \%$ \\
\hline 3. Kepuasan kerja & 0,00 & 1,51 & 13,50 & 75,70 & 34,56 & $82,88 \%$ \\
\hline
\end{tabular}

Sumber : Hasil Peneltian, 2020 (data diolah, dengan SPSS)

Catatan : SS = Sangat setuju, $S=$ Setuju, KS = Kurang setuju, TS = Tidak setuju STS = Sangat tidak setuju)

Berdasarkan tabel di atas dapat dijelaskan bahwa :

1) Variabel Keemimpinan Kepala Sekolah termasuk baik dalam mendukung kinerja guru. Skor penilaian guru atas Kepemimpinan Kepala sekolah mencapai 82,59\%

2) Variabel Tingkat Motivasi kerja guru, sudah baik mencapai $82,27 \%$ dari kondisi yang ideal dalam mencapai kinerja guru, 
3) Kepuasan kerja guru sudah menunjukkan hal yang baik, mencapai $82,88 \%$ dari yang diharapkan untuk meningkatkan kinerja guru.

\section{c. Hasil Analisis Jalur}

Dalam penelitian ini model analisis dengan analisi jalur yang menentukan pengaruh Kepemimpinan , komunikasi dan disiplin kerja terhadap kinerja pegawai. Dengan model $Y=f(X 1, X 2, X 3)=\rho_{1} X_{1}+\rho_{2} X_{2}+$ $\rho_{3} X_{3}+$ e. Adapun pembuktian hipotesis secara simultan dapat dilihat pada tabel berikut ini:

Tabel 6. Uji Model Sruktural (Uji Secara Simultan)

\begin{tabular}{|l|l|c|c|c|c|c|}
\hline \multicolumn{2}{|l|}{ Model } & Sum of Squares & df & Mean Square & F & Sig. \\
\hline \multirow{2}{*}{ Regression } & 458.215 & 3 & 152.738 & 18.001 & $.000^{\text {a }}$ \\
\cline { 2 - 7 } & Residual & 950.311 & 112 & 8.485 & & \\
\hline Total & 1408.526 & 115 & & & \\
\hline
\end{tabular}

a. Predictors: (Constant), Kepuasan kerja, Motivasi, Kepemimpinan

b. Dependent Variable: Kinerja

Sumber: Data olahan, 2020 (diolah dengan SPSS)

Berdasarkan hasil uji $\mathrm{F}$ diperoleh nilai $\mathrm{F}_{\text {hitung }}$ sebesar 18,001. Sementara nilai signifikansinya 0,000. Hal ini menunjukkan model regresi antar variabel signifikansi linier. Maka model analisi jalur dalam bentuk $\mathrm{Y}=$ $f(X 1, X 2, X 3)=\rho_{1} X_{1}+\rho_{2} X_{2}+\rho_{3} X_{3}$ diterima.

\section{1). Pengujian Hipotesis Penelitian}

Dalam hal ini hipotesis yang diajukan selanjutnya diuji untuk menjawab masalah penelitian yang dirumuskan. Hasil pengolahan data dalam menaksir koefisiein jalur dan uji signifikansinya;

Tabel 7. Taksiran Koefisien Jalur Variabel Bebas (Eksogenus) dan Uji-t

\begin{tabular}{|l|c|c|c|}
\hline \multirow{2}{*}{ Model } & Unstandardized Coefficients & t & \multirow{2}{*}{ Sig. } \\
\cline { 2 - 2 } Kepemimpinan & Beta & 2.222 & .028 \\
\hline Motivasi & .196 & 2.153 & .033 \\
\hline Kepuasan & .207 & 3.258 & .001 \\
\hline
\end{tabular}

a. Dependent Variable: Kinerja

Uji hipotesis:

Hipotesis-1:

Ho: $\rho_{\mathrm{zx} 1} \leq 0$ : Kepemimpinan tidak berpengaruh terhadap Kinerja guru

$\mathrm{H}_{1}: \rho_{\mathrm{zx} 1}>0$ : Kepemimpinan berpengaruh terhadap Kinerja guru

Kriteria pengujian adalah total Ho jika $t_{\text {hitung }}>t_{\text {tabel }}$ dimana $t_{\text {tabel }}$ untuk $\alpha=5 \%$ adalah 1,980 . Hipotesis ini menyatakan ada pengaruh Kepemimpinan $\left(\mathrm{X}_{1}\right)$ terhadap Kinerja guru $(\mathrm{Y})$. Dengan koefisien jalurnya $\rho_{\mathrm{yx} 1}=$ 0,196 . Hasil perhitungan uji individu menunjukkan harga $t_{\text {hitung }}$ sebesar 2,222. Dengan demikian $t_{\text {hitung }}>t_{\text {tabel }}$ (2,222> 1,980). Sehingga $H_{1}$ diterima artinya koefisien jalur Kepemimpinan $\left(X_{1}\right)$ terhadap Kinerja guru(Y) dapat dinyatakan signifikan pada taraf signifikan $\alpha=0,05$.

Hipotesis 2

Ho: $\rho_{\mathrm{yx} 2} \leq 0$ : Motivasi tidak berpengaruh terhadap Kinerja guru

$\mathrm{H}_{1}: \rho_{\mathrm{yx} 2}>0$ : Motivasi berpengaruh terhadap Kinerja guru

Hipotesis ini menyatakan ada pengaruh motivasi $\left(\mathrm{X}_{2}\right)$ terhadap Kinerja guru $(\mathrm{Y})$. Dengan koefisien jalurnya $\rho_{\mathrm{yx} 2}=0,207$. Hasil perhitungan uji individu menunjukkan harga $t_{\text {hitung }}$ sebesar 2,153 . Dengan demikian $t_{\text {hitung }}$ $>t_{\text {tabel }}(2,153>1,980)$. Sehingga $H_{1}$ diterima, yang artinya koefisien jalur variabel motivasi $\left(\mathrm{X}_{2}\right)$ berpengaruh terhadap Kinerja guru (Y).

Hipotesis 3

Ho: $\rho_{\mathrm{yz} 3} \leq 0$ : Kepuasan kerja tidak berpengaruh terhadap Kinerja guru

$\mathrm{H}_{1}: \rho_{\mathrm{yx} 3}>0$ : Kepuasan kerja berpengaruh terhadap Kinerja guru

Hipotesis ini menyatakan ada pengaruh kepuasan kerja berpengaruh terhadap Kinerja guru (Y). Dengan koefisien jalurnya $\rho_{\mathrm{zyx} 3}=0,306$. Hasil perhitungan uji individu menunjukkan harga $\mathrm{t}_{\text {hitung }}$ sebesar 3,258 . 
Dengan demikian $t_{\text {hitung }}>t_{\text {tabel }}(3,258>1,980)$. Sehingga $H_{1}$ diterima artinya koefisien jalur variabel kepuasan kerja $\left(\mathrm{X}_{3}\right)$ berpengaruh terhadap Kinerja guru $(\mathrm{Y})$, secara signifikan pada taraf uji $\alpha=0,05$.

\section{2). Menentukan Model Struktural}

Setelah terbukti adanya hubungan dan pengaruh secara signifikans antara variabel eksogen terhadap variabel endogen dalam penelitian ini, lalu dilakukan taksiran nilai kausalitas antar variabel eksogen $\left(\mathrm{X}_{1}\right.$, $\mathrm{X}_{2}, \mathrm{X}_{3}$ ) pada tabel 8, dan taksiran koefisien jalur pada tabel 5, yakni :

Tabel 8. Hubungan Kausal Antar Variabel Bebas (Eksogenus)

\begin{tabular}{|l|l|c|c|c|}
\hline & & Kepemimpinan & Motivasi & Kepuasan Kerja \\
\hline \multirow{3}{*}{ Kepemimpinan } & Pearson Correlation & 1 & $.437^{* *}$ & $.394^{* *}$ \\
\cline { 2 - 5 } & Sig. (2-tailed) & & .000 & .000 \\
\cline { 2 - 5 } & $\mathrm{N}$ & 116 & 116 & 116 \\
\hline \multirow{3}{*}{ Motivasi } & Pearson Correlation & $.437^{* *}$ & 1 & $.534^{* *}$ \\
\cline { 2 - 5 } & Sig. (2-tailed) & .000 & & .000 \\
\cline { 2 - 5 } & $\mathrm{N}$ & 116 & 116 & 116 \\
\hline \multirow{3}{*}{ Kepuasan Kerja } & Pearson Correlation & $.394^{* *}$ & $.534^{* *}$ & 1 \\
\cline { 2 - 5 } & Sig. (2-tailed) & .000 & .000 & \\
\cline { 2 - 5 } & $\mathrm{N}$ & 116 & 116 & 116 \\
\hline
\end{tabular}

**. Correlation is significant at the 0.01 level (2-tailed).

Berdasarkan antar variabel eksogen, dan nilai koefisien jalur $(\rho)$, maka model kausal yang dibentuk secara teoritik diperoleh diagram jalur seperti gambar 2.

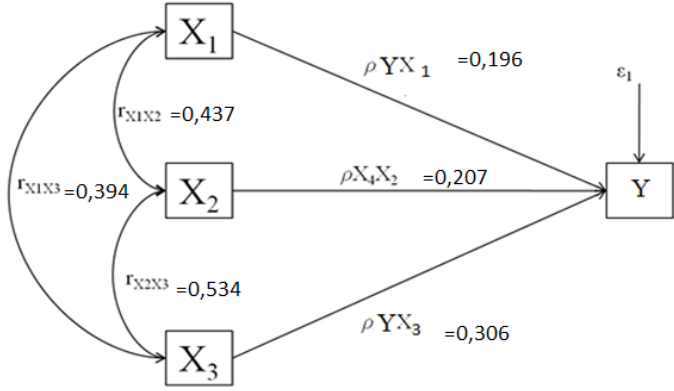

Gambar 2. Diagram Jalur Penelitian

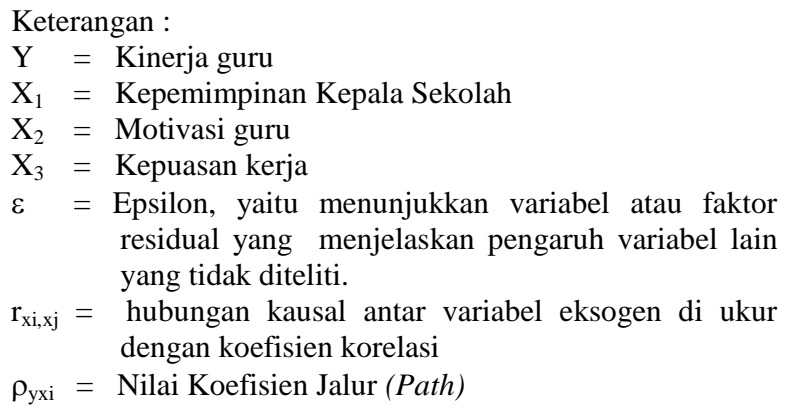

Keterangan :

$\mathrm{X}_{1}=$ Kepemimpinan Kepala Sekolah

$\mathrm{X}_{2}=$ Motivasi guru

$\mathrm{X}_{3}=$ Kepuasan kerja

Epsilon, yaitu menunjukkan variabel atau faktor residual yang menjelaskan pengaruh variabel lain yang tidak diteliti. dengan koefisien korelasi

\section{d. Pembahasan}

\section{1). Pengaruh Kepemimpinan Kepala Sekolah terhadap Kinerja Guru}

Hasil analisis data sebelumnya, menunjukkan adanya pengaruh Kepemimpinan Kepala Sekolah terhadap kinerja guru. Adapun besarnya pengaruh, langsung ataupun tidak langsung karena terdapat hubungan kausalitas antara variabel Kepemimpinan dengan motivasi dan kepuasan kerja, ditentukan berikut ini:

Besarnya pengaruh langsung Kepemimpinan Kepala Sekolah $\left(\mathrm{X}_{1}\right)$ terhadap kinerja guru (Y), dinyatakan dengan besaran koefisien jalur $\left(\rho_{\mathrm{zx} 1}=0,196\right)$, Sehingga besarnya pengaruh langsung ini adalah: 3,84 persen.

Besarnya pengaruh tak langsung Kepemimpinan $\left(\mathrm{X}_{1}\right)$ terhadap kinerja pegawai $(\mathrm{Y})$, karena adanya hubungan kausal dalam variabel eksogen, sehingga di hitung sebagai berikut:

- Pengaruh Kepemimpinan dan motivasi terhadap kinerja guru, adalah: $(0,196)(0,437)(0,207) \times 100 \%=$ $1,77 \%$

- Pengaruh Kepemimpinan dan kepuasan kerja terhadap kinerja guru, adalah: $(0,196)(0,394)(0,306) \mathrm{x}$ $100 \%=2,36 \%$

Maka Pengaruh Total Kepemimpinan Kepala Sekolah $\left(\mathrm{X}_{1}\right)$ terhadap kinerja guru adalah 7,97 persen.

\section{2). Pengaruh Motivasi terhadap Kinerja Guru}

Hasil analisis data sebelumnya, menunjukkan adanya pengaruh motivasi terhadap kinerja guru. Adapun besarnya pengaruh langsung ataupun tidak langsung karena terdapat hubungan kausalitas antara variabel eksogen, ditentukan berikut ini: 
Besarnya pengaruh langsung motivasi $\left(\mathrm{X}_{2}\right)$ terhadap kinerja guru $(\mathrm{Y})$, dinyatakan dengan besaran koefisien jalur $\left(\rho_{\mathrm{yx} 2}=0,207\right)$, Sehingga besarnya pengaruh langsung ini adalah: $4,28 \%$.

Besarnya pengaruh tidak langsung:

- Pengaruh motivasi dan Kepemimpinan terhadap kinerja guru, adalah: $(0,207)(0,437)(0,196) \times 100 \%=$ $1,77 \%$

- Pengaruh motivasi dengan kepuasan kerja terhadap kinerja guru, adalah: $(0,207)(0,534)(0,306) \times 100 \%=$ $3,38 \%$.

Maka Pengaruh Total motivasi $\left(\mathrm{X}_{2}\right)$ terhadap kinerja guru $(\mathrm{Y})$ adalah 9,44 persen.

\section{3). Pengaruh Kepuasan kerja terhadap Kinerja huru}

Hasil analisis data sebelumnya, menunjukkan adanya pengaruh kepuasan kerja terhadap kinerja guru. Maka besarnya pengaruh langsung ataupun tak langsnung, ditentukan berikut ini:

Besarnya pengaruh langsung kepuasan kerja terhadap kinerja guru dinyatakan dengan besaran koefisien jalur $\left(\rho_{y \times 3}=306\right)$, Sehingga besarnya pengaruh langsung ini adalah: $9,36 \%$.

- Pengaruh kepuasan kerja dan Kepemimpinan terhadap kinerja guru, adalah: $(0,306)(0,394)(0,196) \mathrm{x}$ $100 \%=2,36 \%$

- Pengaruh kepuasan kerja dan motivasi terhadap kinerja guru, adalah $(0,306)(0,534)(0,207) \times 100 \%=$ $3,38 \%$.

Maka pengaruh Total Kepuasan kerja $\left(\mathrm{X}_{3}\right)$ terhadap kinerja guru $(\mathrm{Y})$, adalah dengan 15,11 persen.

\section{4). Pengaruh Kepemimpinan Kepala Sekolah, Motivasi dan Kepuasan kerja terhadap Kinerja Guru}

Berdasarkan model struktural yang dikaji dan dibahas sebelumnya, maka dapat di perdalam dengan melibatkan ketiga faktor yang diduga berpengaruh pada kinerja pegawai, yakni faktor Kepemimpinan Kepala sekolah, motivasi dan kepuasan kerja terhadap kinerja guru secara simultan, yakni dengan menghitung korelasi dan determinasi antar variabel ini, yakni sebagai berikut:

a). Korelasi antar Kepemimpinan Kepala sekolah, Motivasi dan Kepuasan kerja terhadap kinerja guru secara simultan

Berdasarkan hitungan korelasi dan determinasi antar variabel Kepemimpinan Kepala sekolah, Motivasi dan Kepuasan kerja terhadap kinerja guru, sebagaimana ditunjukkan dalam tabel berikut :

Tabel 9. Korelasi dan Determinasi antar variabel

\begin{tabular}{|c|c|c|c|}
\hline $\mathrm{R}$ & R Square & Adjusted R Square & Std. Error of the Estimate \\
\hline $.570^{\mathrm{a}}$ & .325 & .307 & 2.912889 \\
\hline
\end{tabular}

Maka dari informasi diatas, terdapat sebesar 0,570 korelasi antar variabel Kepemimpinan Kepala sekolah, Motivasi dan Kepuasan kerja terhadap kinerja guru,. Ini menunjukkan hubungan yang sedang dengan derajat 0,570 dan hubungannya positip.

Dan Hasil koefsiein determinasinya $\left(\mathrm{R}^{2}\right)$ adalah sebesar 0,325 yang dimaknai bahwa terdapat sebesar 32,5 $\%$ kontribusi atau peranan adanya faktor Kepemimpinan Kepala sekolah, Motivasi dan Kepuasan kerja terhadap kinerja guru. Dan sisanya yakni sekitar 67,5\% dipengaruhi oleh faktor lain, seperti kompensasi, fasilitas, budaya kerja dan pelatihan, atau lainnya yang mengikat terhadap kinerja guru.

\section{Simpulan (Conclusion)}

Sebagaimana tujuan dari penelitian ini, maka dari hasil penelitian dan pembahasan yang dilakukan, dapat ditarik beberapa simpulan penting sebagai rangkuman dan temuan hasil penelitian, yakni:

1. Hasil analisis deskriptif menunjukkan bahwa

a). Variabel Kepemimpinan Kepala Sekolah termasuk baik dalam mendukung kinerja guru. Skor penilaian guru atas Kepemimpinan Kepala sekolah mencapai 82,59\%

b). Variabel Tingkat Motivasi kerja guru, sudah baik mencapai $82,27 \%$ dari kondisi yang ideal dalam mencapai kinerja guru,

c). Kepuasan kerja guru sudah menunjukkan hal yang baik, mencapai $82,88 \%$ dari yang diharapkan untuk meningkatkan kinerja guru. 
2. Demikian juga dari hasil analisis jalur, menunjukkan adanya pengaruh Kepemimpinan Kepala Sekolah terhadap Kinerja guru adalah sebesar 7,97\%.

3. Dan dari hasil analisis selanjutnya, menunjukkan adanya pengaruh faktor Motivasi kerja guru terhadap Kinerja guru SMAN se-Kota Juang Kabupaten Bireuen, yakni sebesar 9,44 persen.

4. Sedangkan faktor kepuasan kerja, adalah faktor yang sangat tinggi pengaruhnya terhadap kinerja guru, yakni sebesar $15,11 \%$.

5. Hasil analisis dari nilai koefisien determinasi menjelaskan bahwa kontribusi faktor Kepemimpinan Kepala Sekolah, Motivasi kerja dan Kepuasan kerja guru terhadap Kinerja guru SMAN se-Kota Juang Kabupaten Bireuen, sebesar 26,2 \%. Sementara sisanya dari peran variabel yang tidak diteliti sebesar $72,8 \%$. Hal ini menujukkan bahwa terdapat faktor-faktor lain yang dapat mempengaruhi variabel kinerja guru SMAN se-Kota Juang Kabupaten Bireuen, seperti iklim organisasi, fasilitas kerja, Pendidikan dan Pelatihan, konpensasi, dan lain-lain.

\section{DAFTAR PUSTAKA (References)}

1) Drucker, Peter. 2008. Peter F. Drucker. Tentang Kepemimpinan dan Efektivitas Eksekutif dalam The Leader of the Future, Visi, Strategi dan Praktek Pemimpin Masa Depan untuk Era Baru. Jakarta. Elex Media Komputindo.

2) Eri Agustin, 2015. Pengaruh Motivasi Kerja Terhadap Kinerja Guru Sekolah Dasar Dabin IV Kecamatan Kajen Kabupaten Pekalongan. Skripsi, Jurusan Pendidikan Guru Sekolah Dasar, Fakultas Ilmu Pendidikan, Universitas Negeri Semarang.

3) Febry Zakharia, 2014. Pengaruh Budaya Organisasi Dan Kepuasan Kerja Terhadap Kinerja Guru Smp Yadika 3 Tangerang, Jurnal Ilmu Ekonomi Dan Sosial, Jilid 3, Nomor 1, Juli 2014, Hlm. 39 - 50

4) Handako, Hani T. 2011. Manajemen Personalia dan Sumber Daya Manusia. Yogyakarta. BPFE.

5) Kartono, Kartini. 2005. Pemimpin dan Kepemimpinan. Jakarta. Rajawali Press

6) Mangkunegara, Anwar Prabu. 2009. Evaluasi Kinerja SDM. Bandung: PT. Revika Aditama.

7) Pujiyanti -, SB.Handayani, 2012. Pengaruh Kepuasan Kerja Terhadap Kinerja Guru Dengan Kepemimpinan Kepala Sekolah Dan Pemberdayaan Guru Sebagai Variabel Moderasi Pada SD Negeri UPTD Dikpora Kecamatan Sayung Demak, Jurnal Ekonomi Manajemen Akuntansi Vol 19, No $33(2012)$

8) Rivai, Veithzal. 2009. Manajemen Sumber Daya Manusia untuk Perusahaan dari Teori ke Praktik. Jakarta: PT. Raja Grafindo Persada.

9) Siagian, Sondang P. 2008. Manajemen Sumber Daya Manusia. Jakarta. Bumi Aksara.

10) Sugiyono, 2012. Metode Penelitian Bisnis. Bandung: CV. Alfabeta

11) Suwarto, 2012. Perilaku Keorganisasian. Edisi Kedua. Yogyakarta: Universitas Atma Jaya.

12) Umar, Husein. 2008. Metode Penelitian untuk Skripsi dan Tesis Bisnis.ed kedua. Jakarta. Rajawali Press.

13) Thoha, 2010. Kepemimpinan dalam manajemen, cetakan ke II. Jakarta: Grafindo Persada

14) Winarto Yudhi, 2004. Pengaruh Kepemimpinan terhadap Peningkatan Kinerja Guru dan Karyawan di SMAN 2 Batu. Tesis STIE Mahardhika, Surabaya.

15) Undang-undang Nomor 20 Tahun 2003 tentang Sistem Pendidikan Nasional,

16) Undang Undang Nomor 14 tahun 2005 tentang Guru dan Dosen

17) Peraturan Pemerintah Nomor 19 tahun 2005 tentang Standar Nasional Pendidikan. Undang-undang 